\title{
Policy Paper: Northern Ireland and the Brave New World of Brexit
}

October 2017

ESRC Newcastle-Durham IAA Fund

www.niconstitution.org

@NIConstitution

Sylvia de Mars (Lecturer, Newcastle University

C.R.G. Murray (Senior Lecturer, Newcastle University)

Aoife O’Donoghue (Professor, Durham University)

Ben T.C. Warwick (Lecturer, University of Birmingham) 


\section{Introduction}

This policy paper is part of an extended research project examining the impact upon Northern Ireland of the UK's changing relationship with Europe. ${ }^{1}$ With October 2017 witnessing the beginning of consideration of amendments to the EU Withdrawal Bill and the culmination of efforts to address aspects of Brexit affecting the island of Ireland in Phase 1 of the UK's withdrawal negotiations this paper is intended to focus on some of the emerging issues for Northern Ireland as the contours of Brexit become increasingly defined.

This paper is based on two considerations. First the UK Government maintains that the UK will not be part of the existing EU customs union (EUCU) or indeed the Single Market after Brexit. Second, the EU's proposal for a form of special status for Northern Ireland which moves the customs border to the Irish Sea has been rejected as both undermining the UK's Union and creating a barrier to trade within the UK. If neither of these premises change then they will almost invariably create considerable friction at the Northern Ireland/Ireland border. The UK Government's goal of establishing a bespoke trading arrangement with the EU which allows it to strike wide-ranging trade deals with non-EU countries, and its goal of minimising disruption at the Northern Ireland/Ireland border are incompatible.

In light of these premises, certain aspects of international law will likely come to play an increasingly prominent role in policy making within UK institutions affecting Northern Ireland. First, some aspects of international law have for many decades been mediated through the EU, such as trade law, and will once again need to be managed by the UK Government. Second, some of the UK's international law obligations have been negotiated, implemented and interpreted in light of the UK's EU membership in its negotiation, including aspects of the Good Friday/Belfast Agreement (GFA) and the Common Travel Area.

\section{The Brave New World of the Common Travel Area}

An assumption abounds that the Common Travel Area (CTA) resolves a lot of problems at the Ireland/Northern Ireland border after Brexit, but the UK Governent's position paper acknowledges that the CTA will not, of itself, secure a friction-free border. ${ }^{2}$ The CTA, which (as is repeatedly stated) pre-dates EU membership, is based on the idea that the UK and the Republic can decide for themselves who their citizens are and who the people are who they treat like citizens (but who technically are not). So, this enables Irish citizens in the UK and vice versa to carry on their lives as if they are citizens of each country. This has been the case since the foundation of the Free State. However, this does not cover trade in goods or services.

So, while the CTA resolves, partially, an immigration question it does not resolve the customs issue. The Common Travel Area is not a common trade area, let alone a common market.

A further critical point is, of course, that we cannot return to the CTA as it was in 1973. The Republic of Ireland is in a substantially different position and has a raft of supranational obligations that means it has far less scope for action - even operating under the presumption

\footnotetext{
${ }^{1}$ This work was supported by the Economic and Social Research Council, Impact Acceleration Account [Grant Ref: ES/M500513/1, Newcastle University. This paper is presented in a personal capacity and does not represent the views of the ESRC or of Newcastle, Durham or Birmingham Universities.

${ }^{2}$ HM Government, Position Paper: Northern Ireland and Ireland (16 August 2017) para. 34.
} 
that Dublin wishes to deviate from EU integration for the sake of the CTA. Further, as an international arrangement other, newer, obligations may supersede the CTA, for instance Ireland's continued EU membership. EU membership is also in the Irish Constitution and Ireland's continued mandate to remain a member is sustained through various referenda. While the CTA in and of itself is not hugely problematic as it is more about rights of citizens in both states, we cannot return to the status quo ante either and it does not resolve trade issues.

With regard to social security coordination the exemption under Protocol 20 does not negate that there is an obligation under EU law for all EU member states to extend benefits stemming from bilateral agreements that fall within the scope of EU law to all EU nationals. ${ }^{3}$ In other words, if an Irish worker travels to the UK (under the CTA) and collects social security there and that social security collection is transportable back to Ireland for aggregation purposes, the same would have to happen to a French or a German worker in the UK who collects social security (under UK law) and then moves to Ireland. This will require social security coordinating mechanisms that are very similar to those currently required under EU law (ie Regulation $883 / 2004$ ) in the UK as well as in Ireland, so the information can be easily passed on.

Any further 'firming up' of the CTA will similarly have to be weighed against Protocol 20 - the Protocol permits better treatment for UK nationals in Ireland and Irish nationals in the UK than for all other EU nationals, but where rights extended are equivalent to those applicable under EU law, they have to then be mirrored out to all other EU nationals.

The EU's position is that preservation of the CTA is basically at the will of the UK - if it sets up hard borders, the CTA becomes more difficult; if it does not, the CTA will survive as it is not incompatible with EU law at the moment (and there is an exemption in Protocol 20 at the moment). This really would only change if the UK wished to prevent movement of non-Irish EEA nationals in the future at the border. The UK Government's current proposals point away from border enforcement and instead indicate that the internal enforcement of the 'end of free movement' will take place in the UK (through mechanisms such as landlord and employer checks on rights to work or to residency). ${ }^{4}$

Critically, the UK and Irish Governments have now spent a tremendous amount of time unpicking the CTA and although some questions remain over what legal provisions relate to the CTA and what do not, the obligations owed to each other's nationals are perhaps the clearest they have been since 1921. As it stands the CTA is a tangle of statutes, statutory instruments, practice and one treaty limited to social security provision. To ensure its longevity and to provide security for Irish people resident in the UK (including those from Northern Ireland only holding Irish passports and not wishing to claim their UK passport) and UK citizens from Britain in Ireland, the legal obligations contained in the CTA should now be placed into a treaty between the UK and Ireland.

It took many months to ascertain the full scope of the CT post-Brexit. The CTA in its uncodified form is ripe to be misunderstood and some policy makers continue to speak as if it is all that is necessary to maintain an open border between Ireland and Northern Ireland

\footnotetext{
${ }^{3}$ C-55/00 Gottardo ECLI:EU:C:2002:16, para. 39.

${ }^{4}$ HM Government, Position Paper: Northern Ireland and Ireland (16 August 2017) para. 33.
} 
after Brexit. The full extent of the CTA urgently needs to be clarified in a bilateral treaty between the UK and Ireland

\section{The Brave New World of World Trade Law}

Brexit changes the basis on which the UK, and necessarily Northern Ireland, trades regionally and globally. The nature of the Northern Ireland border therefore becomes significant. One of the key bodies in ascertaining how the border might work is the World Trade Organisation (WTO). ${ }^{5}$ The WTO is an international organisation aiming to reduce all barriers to trade. It achieves this by acting as a forum for countries to constantly re-negotiate to remove blocks they have on trade. These re-negotiations are called Rounds. Set up in 1995, the WTO is a young organisation by international law standards. Before this the GATT (General Agreement on Tariffs and Trade) coordinated international trade but without a permanent organisation to support it. At the WTO decisions are generally made by consensus (the EU has a block vote of 28 , soon to be 27 ). The WTO has 164 members. ${ }^{6}$ The EU is the only organisation to be a member of the WTO. All EU member states are also individual members but they always vote as the EU bloc. So, the EU's voting and other obligations are entirely bound together, there is no discretion to act individually. All other members are states or, like Hong Kong, have separate membership of the WTO to their status within a country.

\section{a) Trading on WTO terms or WTO default rules}

The WTO does not have a set of minimum tariffs or rules with which each country must comply. Instead, it has two main elements.

First, it requires each country to set out a list of its tariff rates for each product and each trade barriers for all services. Each tariff or barrier set for a product and service is subject to negotiation with each other member of the WTO. Whether another member seeks to negotiate these tariffs or other potential trade restrictions depends upon whether they have an interest in that product. So, if you make jeans you are interested in cotton tariffs but probably not interested in yams if hardly anyone in your country eats them.

For large trading states like the USA, China or Brazil these lists or schedules can be extremely long. The EU has a single schedule for all its members and it is quite extensive.

Second, the WTO requires states to apply their individual schedules, and non-tariff rules on packaging or licensing etc., in a non-discriminatory way.

\section{b) Most-Favoured Nation and National Treatment rules}

This non-discrimination breaks down into two basic rules. The first, Most-Favoured Nation, means you must give whatever your best treatment is for foreign products coming into your country to all members of the WTO. For example, if a country cut the tariff on imports of copper from $10 \%$ to $5 \%$ for exporters from one country, it would have to charge $5 \%$ to every other country as well.

The second basic rule, National Treatment, means that you must give your best internal conditions to foreign products or services. For example, if you do not require domestic

\footnotetext{
${ }^{5}$ https://www.wto.org/english/thewto e/thewto e.htm

${ }_{6}^{6}$ https://www.wto.org/english/thewto_e/whatis e/tif_e/org6 e.htm
} 
products to have a warning as to sugar content in food you cannot require it of foreign products.

These requirements are set out in detail in the WTO's core treaties: GATT (General Agreement on Tariffs and Trade), GATS (General Agreement on Trade in Services) and TRIPs (Trade Related Intellectual Property Rights). There is, however, an important exception. Parties to a customs union or free trade area can treat products and services produced within that area better than they treat those of other WTO members. The EU is an example of a customs union. EFTA is an example of a Free Trade Area. The rise of Mega Regionals such as TTIP and TPP provide further examples of such deep integration.

The main purpose of the WTO is to be a forum for negotiation. While the WTO is seen by its members to work well, it is worth bearing in mind that its negotiations are long and arduous. But the WTO remains the quickest way to get things done - once you negotiate down one barrier it goes down for 163 other countries, meaning bigger global effects. National treatment prevents you from sneakily undoing that commitment by referencing your domestic products. But, because of the ramifications for products, countries are slow to remove their most important forms of protection. There is a clear distinction between the WTO default rules that the UK might be reliant upon and the trade deals that it aims to negotiate post Brexit albeit in the context of mega regionals the new trade environment is probably more complex than is presented.

\section{c) Default Rules}

We should be clear what the so-called default WTO rules actually would mean.

First there is a question about what default rules we would be talking about.

The EU has a schedule of concessions - a single list of tariff rates and non-tariff barriers (red tape of a kind) which currently acts simultaneously as the UK's schedule of concessions. So, the default rules are the EU rules - it's the EU's Schedule.

But this is not as straightforward as it sounds. Upon Brexit, there are two options as the UK needs to establish its place within the WTO, not as a new member, but in an entirely sui generis position.

1. All members of the WTO including the EU agree that the UK continues with the EU's Schedule and re-negotiates over time.

2. Members decide that the UK should not be entitled to use the EU's schedule and must renegotiate its own with all members due to the change in circumstances.

While the Director General of the WTO, Roberto Azevêdo, has been clear that it wishes to be accommodating there is no clear agreement as to what that might entail. It is also worth stressing that this is probably not up to the WTO as an organisation, but rather up to the Member States of the WTO - who are the sole decision-makers within the WTO.

Julian Braithwaite the UK Ambassador and Permanent Representative to the WTO, set out how the UK was going about the smooth transition at the WTO:

There is a process in the WTO that allows the UK to submit new schedules. But they can only be adopted - or certified - and thus replace our existing EU schedules if none of the WTO's other 163 members object to them. So to minimise any grounds for 
objection, we plan to replicate our existing trade regime as far as possible in our new schedules. Before we take any formal steps in the WTO we will hold extensive informal consultations with the WTO membership. Every member will have an opportunity to raise any issues or concerns with us before we proceed. ${ }^{7}$

There are plans by the EU and UK to submit a plan to the WTO about how they envisage this happening, however, this is also reliant on broader Brexit negotiations moving forward and the other members' reactions:

The international trading community faces many uncertainties - notably over Brexit, which will have implications for the EU's trading partners and the EU's WTO Schedule of Commitments. In this regard, Members expected that any process to make adjustments to the Schedule of the EU as a result of Brexit would be open, transparent, WTOcompliant, and include consultations with third countries. ${ }^{8}$

For Northern Ireland, agriculture and agricultural products is clearly an important issue. Indonesia asked the WTO's Agriculture Committee about how the UK would handle its agricultural tariff system and preferential trade scheme for poorer countries after Brexit, and the United States, Argentina, China and Russia all registered interest in the answer. The EU answer was basically that this depended on the negotiations. Agriculture is a perennial difficulty for the WTO and was one of the main reasons for the failure of the Doha Round.

If the Schedules for Goods and Services remain as with the EU until they are re-negotiated there remains a significant impact. If there is no unique 'Northern Ireland' solution, no special border solution and no trade deal with the EU the 'default' rules have significant consequences.

It is easy to assume that such changes will only hit business and not the private consumer, however, this is only a partial view. For instance, just as gifts above a certain value from the US are subject to customs, packages sent between relatives in Ireland and Northern Ireland would also have to pay. Personal items are ordinarily exempted from border charges; but anyone operating a small business, or moving products across the border for work purposes, would need to declare what those products are and pay levies on them according to the EU's WTO tariffs.

While a lot of products come with a $0 \%$ tariff, not all sectors benefit from 'free' imports and exports. Cigarettes and cigars, for instance, are hit with a $33-58 \%$ import duty. A wide variety of consumer products, such as make-up and personal hygiene items, textiles and basic building construction items (such as doors and windows) face import charges of between 4 and $8 \%$. Clothing is generally met with import duties ranging from 8 to 17\%, and cars face import duties of $10-20 \%$ depending on their size and purpose. ${ }^{9}$

\footnotetext{
7 See D. Green, 'Brexit and the issue of the WTO schedules' Financial Times (28 February 2017) https://www.ft.com/content/42b59126-794c-3a0b-b19a-6d4b0a11c990.

${ }^{8}$ EU Trade Policy Review (7 July 2017) https://www.wto.org/english/tratop e/tpr e/tp457 crc e.htm.

9 Details on the EU's tariff schedules can be found here: https://www.wto.org/english/thewto e/countries_e/european_communities_e.htm.
} 
In the end, as import tariffs are always pushed onto the consumer within the purchasing price, many products moving across the border could suddenly become anywhere from $5 \%$ to $25 \%$ more expensive.

The impact upon the agri-food and farming sector is particularly revealing. Most agricultural products and livestock are subject to EU import tariffs of between $6 \%$ and $22 \%$. UK agri-food products would either have to compete with heavily subsided EU produce on the global market by reducing their basic costs in order to be competitively priced, or target sales within the UK to avoid import duties. It is likely that suppliers will use the cheapest available option which, due to CAP subsidies, may very well still be EU products, even with the imposition of UK tariffs on imports from the EU.

The devaluation of the pound against major global currencies might rescue domestic producers, as the price of foreign products will feel higher due to the weak purchasing power of sterling. This might - to a minor extent and in the short-term - push customers towards buying British.

But of course, beyond tariffs there are other measures such as Sanitary and Phytosanitary Measures (SPS) that most countries require for the export of both live produce and agri-food products. ${ }^{10}$ To maintain access, it may be that third countries require that the UK maintains the standards it had with the EU to continue access - and guarantee that products which have to adhere to lower standards - for instance coming from the US - do not transit through the UK and 'become' UK produce. An example, perhaps, would be US chlorinated chicken transiting through the UK into the EU market and undercutting equivalents such as Moy Park.

Devaluation of the currency is, of course, of no comfort to businesses which cannot source elements of their production line within the UK and which will be liable for a double hit: more expensive imports as a result of the weak pound, and being subject to a period of uncertainty about what the UK's import tariffs will eventually be.

A triple element of jeopardy might be added for such global companies with complex supply chains: if they wish to export their final product back into the EU or global markets, they might be hit by import tariffs to get their product to its final destination. Bombardier, Caterpillar, Fujitsu and DuPont are all examples of companies in exactly such a position. The rules of origin with the WTO are quite complex but are clear in determining where a product is actually made.

Services are obviously a key sector for the London economy and are critical to the national economy. Under the EU free movement of services rules, both to set up a business abroad and to work (whether for a day, a week, or a year) in many sectors is relatively straightforward. Post Brexit, under the WTO, these would be covered by GATS which is significantly less open to services movement than the EU is. Non-EU nationals living in the UK and temporarily staying and working in the EU, unless they are in senior management, will find far more barriers to travel. Post-Brexit, virtually all UK nationals would need to satisfy national immigration requirements to temporarily stay and work in any of the 27 EU Member States. In principle this could include Ireland, however the CTA may assist in this specific regard for Irish nationals moving to the UK (but not necessarily vice versa).

\footnotetext{
${ }^{10}$ HM Government, Position Paper: Northern Ireland and Ireland (16 August 2017) para. 57.
} 
Elements of the CTA, with EU agreement, might permit some differences within Ireland but this will be the subject of tricky negotiations and it may have to meet the criteria of a Free Trade Area under WTO rules to be an exception to GATS.

\section{d) Conclusion}

Resort to the default WTO rules, sometimes refered to as a 'cliff edge' exit from the EU, would have an immediate and significant impact on Northern Ireland, both on industry and consumers. Even with the maintenance of the CTA and of EU citizenship rights for individuals born in Northern Ireland, trade in goods and services, particularly agricultural and agri-food products, will be affected.

While the actual outcome will probably be on a spectrum from staying in the Common Market to the WTO default rules, any exit agreement closer to the WTO spectrum will lead to a significant re-adjustment to the realities of trading outside of the EU buffer. The heft the EU had as 28 bloc (and then 27), with three of the ten biggest economies in the world still in the bloc, remains significant. The UK is, of course, also amongst the 10 biggest economies, but its negotiating position within the WTO will not be the equivalent of what it is for as long as it remains part of the EU's much bigger (indeed the world's biggest) market.

The assumption persists that the UK will be able to retain existing trade deals negotiated whilst it was part of the EU after Brexit. But other WTO member states could object to such arrangements even if the UK and EU are in agreement on this position. Only if the UK pursues a model of Brexit which sees it maintain the Single Market and EU Customs Union can these risks be averted.

\section{The Brave New World of the Ireland-Northern Ireland or UK-EU Land Border}

The UK's negotiation positions are mutually exclusive; it is not possible to simultaneously exit both the EUCU and the Single Market and fully avoid a physical border. The desire for no special treatment for Northern Ireland in terms of the EUCU makes this more complicated. By maintaining this red line, the UK as a whole will have to set up highly EU-compliant customs arrangements; not merely a customs agreement, but one that obviates the need for any border controls, in order to keep the border fully 'open'. The EU does not have such an arrangement with any third party, and were it to establish one with the UK it would probably require the UK signing up to the EU regulatory regime but without any particular input into that regulatory regime. This is not just a customs regulatory issue; other questions such as data protection to ensure access to data sharing/information exchange and e-customs systems will also come into play.

Regulatory differences create borders. Differences in agricultural or environmental standards will have significant impact on import/export ability - not only in the sense of it becoming more expensive, but genuinely in the sense of 'is it still going to be possible'. Mutual recognition of standards - or regulatory equivalence - would need to become part of any future FTA between the UK and the EU in order to work. As trade is outside of the CTA, Ireland does not stand alone in those FTA negotiations.

Customs does not cover mutual recognition of standards. The EU and Turkey have a customs union; it does not preclude border checks on a wide variety of Turkish products. Even the EEA/EFTA countries, which are within the single market to a significant extent, do not fully 
escape having physical borders with EU member states. These borders differ in how 'hard' to 'light touch' they are - but infrastructure would need to be there, because even where negotiations permit most products to cross borders, it would need to be verified on an ongoing basis that the relevant products meet the agreed-upon standards.

The concerns over chlorinated chicken which surfaced in the summer of 2017 are illustrative. This US agricultural practice is not permitted in the EU. Chlorinated chicken consequently cannot enter the EU. If the UK loosens that restriction subsequent to Brexit in any trade deal with the US, it will find trading with the EU significantly more complicated - businesses seeking to move chicken from the UK into the EU would have to prove it was EU-appropriate chicken. Therefore both chlorinated chicken and all other chicken - if they could in technical terms be kept separate - would need to be distinguishable, or alternatively the EU would have to start accepting chlorinated chicken (which is highly unlikely in terms of its established animal welfare standards). ${ }^{11}$

Differences in environmental standards could have further knock-on consequences, as they may also impact heavily on the ability for UK companies - including from Northern Ireland in projects in Ireland - to participate in other EU projects. For instance, environmental considerations can be taken into account in the award of public procurement contracts, and if the UK did not sustain EU-level environmental standards in the future, a system would need to be developed to ensure that individual contractors could prove they met the EU standards (and were not therefore able to undercut EU suppliers on this basis). This, again, is a trade barrier. It is not one that can be negated outside of mutual recognition of standards, which is what would drop away if EU and UK policy in any area started to differ.

At present the UK Government promises to have appropriate regulations but this is not the same as being legally bound to have those regulations. The EU Treaties mandate those regulations apply within member states. But given that the UK is aiming to have regulatory independence, another source of law will need to replace the EU Treaties but be of an equally binding nature in order to guarantee to the EU that UK products meet the agreed-upon requirements. This will, undoubtedly, involve another form of Treaty - which will require a supervisory authority of some kind. And, where such bilateral agreements exist between the EU and third countries, there are always custom checks to ensure that the agreements that exist operate appropriately in practice.

A Seanad Report suggested the following measures for the Ireland/Northern Ireland border post Brexit:

1. a pre-clearance model for goods as part of a solution, whereby trucks and drivers can pass through the UK land-bridge without incurring duties or checks.

2. A system of pre-registering loads online and tracking using GPS or number plate recognition is a possible solution for trade with Britain and Northern Ireland. ${ }^{12}$

\footnotetext{
${ }^{11}$ See S. Dawson, 'Chlorine-washed chicken Q\&A: food safety expert explains why US poultry is banned in the EU' The Conversation (2 August 2017).

12 Seanad Special Select Committee on Withdrawal of the United Kingdom from the European Union, Brexit: Implications and Potential Solutions (June 2017) 18.
} 
But even with these solutions anti-abuse measures need to be put in place, including mobile spot-checks of goods to check compliance.

The UK Government currently proposes a 'cross-border trade exemption' for small businesses. ${ }^{13}$ This would require all traders to be identifiable in one way or another and to be 'sorted' according to what level of checks are required for them at, presumably, the border. Such a scheme may also be heavily sectoral and will be dependent on definitions of 'small traders' - does this include farmers, and if so, what size of farm will count as 'small'? Moreover, small businesses regularly rely upon large courier companies to make cross-border deliveries, which makes policing such an arrangement particularly complex. There will be significant regulation in place to make such an 'exemption' workable and to ensure that the products in question meet the EU standards needed for import to be at all possible. Even under such an arrangement small businesses will therefore experience increased regulation, even if it is not at the border.

Any approach which does not involved the UK remaining within the EU Single Market and the EU Customs Union will result in the imposition of some physical border controls because the legal guarantees of regulatory equivalence, mutual recognition, and non-barriers will require checks. The extent of these checks depends upon both the solution found for Northern Ireland and the relationship the rest of the UK has with the EU. Currently, there is no technology out there that could get rid of the need for spot checks given the UK Government's wish to leave the Single Market and Custom's Union. The extent of the border remains negotiable, but given the UK's current negotiating position and 'red lines', it is very difficult to perceive a route towards a seamless border.

The UK negotiating position has floated the possibility of the EU ignoring the Northern Ireland/Ireland land border for external tariffs (as happens at the EU's borders with micro states). But the this would create a back door into the EU market and prevent the EU from fulfilling its WTO obligations. Examples of EU border arrangements with third countries which are larger economies give more realistic pictures of post-Brexit possibilities:

Turkey and the EU: This approach does not cover all goods and requires extensive checks on the cross-border movement of goods (relying on transport permits). ${ }^{14}$ It does provide for common external tariffs, however, and the UK would have to agree to these as part of a customs agreement solution. ${ }^{15}$

Sweden/Norway: The EEA does not cover agricultural goods which would present a considerable difficulty for Northern Ireland's cross-border supply chains in the agri-food industry. When it comes to border management, the EEA agreement provides for customs cooperation and mutual assistance, including detailed provisions on issues such as common standards and mutual recognition as regards customs security measures. In the context of the land border between Norway and Sweden, a bilateral agreement dating from 1959 (and

\footnotetext{
${ }^{13}$ HM Government, Position Paper: Northern Ireland and Ireland (16 August 2017) para. 42.

${ }^{14}$ See World Bank, Evaluation of the EU-TURKEY Customs Union (2014). https://ec.europa.eu/neighbourhoodenlargement/sites/near/files/pdf/financial assistance/phare/evaluation/2014/20140403-evaluation-of-the-euturkey-customs-union.pdf.

${ }^{15}$ HM Government, Position Paper: Northern Ireland and Ireland (16 August 2017) para. 48.
} 
applicable subsequent to Sweden's EU accession ${ }^{16}$ ) aims at reducing bureaucracy and duplication while still managing border crossings effectively: for example, providing for a common border zone where each country's customs authorities can operate freely across both territories. ${ }^{17}$ However, it is clear from the Norway example that EEA membership does not negate border checks altogether - there are multiple customs check points at border crossings, and these do not only engage in spot-checks for commercial traffic.

Switzerland/Germany: Switzerland has a special starting position in that it is a member of the Schengen area albeit it is not part of the European Union Customs Union. Due to this fact, customs controls continue. Both countries carry out some checks at the crossings - even on goods transported by individuals on vacation, to ensure they do not violate the personal allowances permitted under the EUCU and Swiss law. Even though technically Switzerland does not control the movement of people, the line between controlling traffic of people and goods is hard to draw - stopping a truck for customs reasons is likely to also result in an ID check for its drivers. Beyond that, because of the dual role of Swiss customs officials, who also act as border police, they are required to carry out ID checks for security issues, and not just at fixed border points but also via mobile units that operate along the border. ${ }^{18}$

Bosnia Herzegovina/Croatia: When Croatia joined the EU in 2013, the bloc's external frontier was redrawn along the country's borders with Serbia, Bosnia and Herzegovina, and Montenegro. The border with Bosnia and Herzegovina has proved particularly troublesome. Both were once republics of Yugoslavia, and $15 \%$ of Bosnian citizens are ethnic Croats, most of whom have Croatian EU passports. All non-EU citizens (including most Bosnians) are subject to passport controls at this border to the EU. However, the EU agreed to a system of permits allowing locals unhindered travel across the border. Prime Minister Theresa May has argued that examples like this show that the EU shows imagination in dealing with tricky border issues in the past - but easy access is not the same as the full absence of a border. Croatia, upon accession, had to build new border posts and is required to perform numerous checks on goods from Bosnia. Exceptions also do not come without strings attached: for Bosnia to benefit from an EU-permitted exception to border controls so that it can easily access its primary port (which is now in Croatian territory) to export agricultural goods, Bosnia has had to agree to comply with the relevant EU regulations on those agricultural products. ${ }^{19}$

East/West Germany: The Seanad considered a protocol that then-West Germany negotiated following the ratification of the Treaty of Rome in 1957: this protocol permitted trade between East and West Germany to be treated as 'internal' trade, rather than cross-border trade. Subsequent treaties, including ones establishing the European [Union] Customs Union, did not

\footnotetext{
${ }^{16}$ See now the bilateral Agreement on customs cooperation in the form of an Exchange of Letters between the European Community and the Kingdom of Norway [1997] OJ L 105/17.

${ }^{17}$ See http://ec.europa.eu/trade/policy/countries-and-regions/countries/norway/.

${ }^{18}$ See https://www.ezv.admin.ch/ezv/en/home/topics/schengen.html.

${ }^{19}$ See http://europa.eu/rapid/press-release SPEECH-13-557 en.htm and Commission Implementing Regulation (EU) No 556/2013 of 14 June 2013 amending Regulations (EC) No 798/2008, (EU) No 206/2010, (EU) No 605/2010 and (EU) No 28/2012 as regards the transit of certain products of animal origin from Bosnia and Herzegovina Text with EEA relevance [2013] OJ L 164/13.
} 
negate this protocol; it became obsolete once Germany was reunified. ${ }^{20}$ The Senead suggests this may be a potential precedent for Northern Ireland, as a protocol could be drafted to designate Northern Ireland as being part of an 'internal' trade area with Ireland. However, such an accommodation would be very difficult politically and given the terms of the GFA with regard to the people of Northern Ireland determining their own future status, it would likely be contested.

The UK remaining within the EU Single Market and the EU Customs Union after Brexit would be the best outcome in terms of minimising friction at the EU's new external border in Northern Ireland. The UK Government currently rejects this option, but its proposed solutions do not take account of the EU's need to protect its international obligations with regard to its trading borders. The UK Government's hints towards mutual non-enforcement of these rules (or an enforcement regime curtailed by loopholes) is tantamount to asking the EU to ignore its own legal duties,. It is an illusory, rather than "imaginative", solution to the border.

\section{The Brave New World of Human Rights}

The Good Friday/Belfast Agreement means that leaving the EU carries with it different challenges in terms of necessary human rights protection for Northern Ireland than for the rest of the UK. Although the short-term possibility of the UK withdrawing from the European Convention of Human Rights has receded as Brexit sucks in so much of Westminster's legislative energy, the GFA requires broad equivalence for rights protections on the island of Ireland and Brexit opens up a possibility for divergence.

Differing human rights provisions, due to devolution, are not without precedent in the UK and this element of UK constitutional structure may prove significant. The Guiding Principles transmitted by the Commission to EU27 for the Dialogue on Ireland/Northern Ireland the EU states that:

The European Union and the United Kingdom, as a co-guarantor with Ireland of the Good Friday Agreement, should continue to support peace, stability and reconciliation on the island of Ireland ...

The Good Friday Agreement includes provisions on Rights, Safeguards and Equality of Opportunity, for which European Union law and practice has provided a supporting framework in Northern Ireland and across the island. The Good Friday Agreement requires equivalent standards of protection of rights in Ireland and Northern Ireland. The United Kingdom should ensure that no diminution of rights is caused by the United Kingdom's departure from the European Union, including in the area of protection against forms of discrimination currently enshrined in Union. ${ }^{21}$

\footnotetext{
${ }^{20}$ Seanad Special Select Committee on Withdrawal of the United Kingdom from the European Union, Brexit: Implications and Potential Solutions (June 2017) 20-21.

${ }^{21}$ EU Commission, Guiding principles transmitted to EU27 for the Dialogue on Ireland/Northern Ireland (2017) TF50 15, 3-4.
} 
While the GFA specifically references the European Convention on Human Rights and this is where much of the focus is, as the EU has pointed out equivalence of rights in general (not just civil and political rights) across the island is required.

Equivalence does not require the law to be exactly the same - for instance the law on same sex marriage is different across the island - however equivalence could potentially require that at least within Northern Ireland, human rights protection that emerges from the EU and not the Council of Europe may need to be maintained in some form. In the Annex to the GFA the equivalence is mentioned with specific reference to the Republic stating that ' $[t]$ he measures brought forward would ensure at least an equivalent level of protection of human rights as will pertain in Northern Ireland' ${ }^{22}$ This could be interpreted in reverse, meaning that a diminution of rights in Northern Ireland would permit the Republic to do the same -- however this would defeat the object and purpose of the GFA that was intended to create an ECHR-plus for Northern Ireland in the context of EU membership. Ireland will obviously maintain its ECHRplus position.

The biggest issue is therefore the Charter of Fundamental Rights (but could potentially also include broader rights that are foundational to the EU, such as workers' rights). It would seem reasonable as an interpretation to suggest that post Brexit the rights that Irish citizens enjoy as EU citizens within the EU would continue and be enforceable within the EU even if they originate in Northern Ireland and these EU citizens also hold UK passports. That seems to be the clear position of all parties to the negotiations.

The difficulty arises if a discrepancy arises between those rights that emerge from EU that are applied in the Republic but are removed subsequent to Brexit. At present, the status quo means there is no issue under the GFA. However, post-Brexit it is possible that the UK may choose to lessen its rights protections that are solely under the Charter (elements of digital protection for instance) thus diminishing the equivalence. Post Brexit, the EU could also upscale its rights protection opening a gap between Ireland and the UK. The most extreme example could be both moving towards opposite ends of the spectrum (the EU/Ireland creating more rights, the UK fewer) creating an equivalence gap which could impact upon the GFA. This is a real risk in the context of Brexit; given that the removal of so-called red tape was a prominent justification for Brexit, this poses a long-term risk to workplace rights and gender equality protections (even if they are initially retained in UK law through the Withdrawal Bill).

The Charter of Fundamental Freedoms is intended to be complementary to the ECHR:

In so far as this Charter contains rights which correspond to rights guaranteed by the Convention for the Protection of Human Rights and Fundamental Freedoms, the meaning and scope of those rights shall be the same as those laid down by the said Convention. This provision shall not prevent Union law providing more extensive protection. $^{23}$

The ECHR is a baseline and the Charter provides more extensive protection - a form of ECHRplus for the EU (it is a more modern rights document and provides a more principled basis for

\footnotetext{
${ }^{22}$ Agreement between the Government of the United Kingdom of Great Britain and Northern Ireland and the Government of Ireland (with annexes) (1998) 2114 UNTS 473.

${ }^{23}$ Article 52(3) Charter of Fundamental Freedoms.
} 
dealing with areas of law which have developed since the ECHR was concluded in the 1950s, such as data protection law). The Charter has a range of civil, political, social and economic rights, under six chapters: Dignity, Freedom, Equality, Solidarity, Citizen's Rights and Justice. The Charter contains both civil and political and socio-economic rights and several are specific to the Charter. For example, the right to the protection of personal data and to dignity, provisions on gender equality in employment, work and pay. A Parliamentary Select Committee has emphasised that the Charter does at present have direct effect in the UK, albeit only as it applies to areas that fall within the scope of EU law. ${ }^{24}$

Clause 5 of the EU Withdrawal Bill, as introduced, potentially prevents the Charter from having this function over "retained" areas of EU law:

cl.5(4) The Charter of Fundamental Rights is not part of domestic law on or after exit day.

cl.5(5) Subsection (4) does not affect the retention in domestic law on or after exit day in accordance with this Act of any fundamental rights or principles which exist irrespective of the Charter (and references to the Charter in any case law are, so far as necessary for this purpose, to be read as if they were references to any corresponding retained fundamental rights or principles).

As clause 5(4) of the Withdrawal Bill indicates, it must be remembered that EU law contains principles and rights beyond the Charter, many of which prima facie be transposed into UK law under the EU Withdrawal Bill:

- The Treaty of Lisbon under Article 3(3) includes children's rights. The UK is in Convention on Rights of the Child as a State so the GFA equivalence should not be affected unless the EU went far beyond the UN Convention.

- The EU has also ratified the UN Convention on the Rights of Persons with Disabilities. UK has its own ratification of this too. Similarly the GFA equivalence should not be affected unless the EU went far beyond the UN Convention.

- The Charter also covers areas such as data protection, privacy and human cloning as well as issues around Elder law.

- EU Secondary legislation covers asylum (Directive 2013/32/EU) and victim's rights (Directive 2012/29/EU).

- Gender equality has also been a significant element of EU law. The TEU under articles 2 and 3 provides for the elimination of inequality and the promotion of equality between men and women. ${ }^{25}$

Even so, if a right is only found in the Charter and not specifically converted into UK law then it could be lost to domestic law on Brexit. The Government has not recognised this as a concern, with the White Paper on Brexit maintaining that:

The Charter applies to EU Member States only when they are acting within the scope of EU law, its relevance to the UK will be 'removed' by the UK's withdrawal from the EU.

\footnotetext{
${ }^{24}$ House of Commons European Scrutiny Committee, The Application of the EU Charter of Fundamental Rights in the UK: A State of Confusion (2013-2014) HC 979, 50-51.

${ }^{25}$ Legislating for Brexit: the Great Repeal Bill Commons Library Briefing No 7793 (2 May 2017).
} 
The Charter should not be used to bring challenges against the Government over EU rights like the right to vote or stand as a candidate in European Parliament elections that will be lost as a result of withdrawal from the EU, or as the basis for striking down UK legislation after withdrawal. As the Charter was not designed to create any new rights or alter the circumstances in which individuals could rely on fundamental rights, removal of the Charter from UK law 'will not affect the substantive rights that individuals already benefit from in the UK'. ${ }^{26}$

The Charter does, however, enunciate principles which underpin areas of current EU competence regarding data protection and social rights. The current Withdrawal Bill proposals intend to strip away the Charter and the principles contained therein but retain (initially at least) the substantive elements of these areas of law. Data protection law is, to take one example, an essential facet of the right to privacy, but because of the nature of EU law the relevant principles are much better developed within the Charter (Article 8 and 52) than under the ECHR (Article 8); 'Article 8 of the Charter concerns a fundamental right which is distinct from that enshrined in Article 7 of the Charter and which has no equivalent in the ECHR'. ${ }^{27}$ The approach set out in clause 5 and clause 6(7) of the Withdrawal Bill creates the potential for gaps to emerge between rights enjoyed in Northern Ireland and in the Republic, and may even lead to their being non-equivalent in GFA terms. Of course, this entirely depends on how these rights develop in practice after Brexit.

Parliament should therefore take steps to introduce additional protections into domestic law to ensure that the absence of the Charter within the domestic framework does not undermine GFA compliance. Several proposed amendments to the Withdrawal Bill attempt this feat. Some target the issue of GFA compliance directly. Amendments 144-147, proposed by the leadership of the Liberal Democrats, seek to restrict the ability of ministers to employ statutory instruments under clause 7 to 9 to act in a way which could undermine legislation consequent upon GFA. The impetus behind this protection is important, but the focus upon consequent legislation is misplaced in the human rights context given that the GFA requires an equivalence standard to be applied to human rights protections in Ireland/Northern Ireland as a whole. ${ }^{28}$ Moreover, these amendments miss their target if clause 5 has by force of statute undermined the human rights equivalence that the GFA requires. ${ }^{29}$

Nor is the EU passive in this process. The UK Government has frequently claimed that it is seeking a comprehensive agreement with the EU after Brexit (bringing in aspects such as security in addition to trade). With regard to Northern Ireland, this has even stretched to proposing that the EU continue to provide funding under its PEACE stream after Brexit. ${ }^{30}$ For the EU, however, a comprehensive agreement would likely also involve data protection, human rights and possibly workers' rights (at the very least to minimise the potential that

\footnotetext{
${ }^{26} \mathrm{HM}$ Government, Legislating for the United Kingdom's withdrawal from the European Union (2017) Cm 9446, para. 2.23.

${ }^{27}$ See C-203/15 and C-698/15 Secretary of State for the Home Department v Watson [2016], [129].

${ }^{28}$ Proposed amendment 25 would also capture this end within its broader terms.

${ }^{29}$ Agreement between the Government of the United Kingdom of Great Britain and Northern Ireland and the Government of Ireland (with annexes) (1998) 2114 UNTS 473, Section 6, para.9.

${ }^{30}$ HM Government, Position Paper: Northern Ireland and Ireland (16 August 2017) para. 8.
} 
companies operating in the UK and trading into the EU under any Brexit agreement could use a lack of such safeguards to undercut their EU-based competitors). The EU and Canada, for example, made reciprocal human rights commitments as part of preamble to CETA. The EU is, indeed, under treaty obligation to conduct its foreign policy respect the principles of 'democracy, the rule of law, the universality and indivisibility of human rights and fundamental freedoms, respect for human dignity, the principles of equality and solidarity .... ${ }^{31}$

Shared EU membership has applied a gloss over domestic policy differences between the UK and Ireland as the same supranational standards could be identified as the reciprocal rights framework. This now changes. The effect of clause 5 will inhibit the UK courts' efforts to draw upon Charter principles and related CJEU jurisprudence to secure continued equivalent compliance as encapsulated in the GFA. This provision should therefore be amended to specifically protect this GFA requirement, which the EU could indeed regard as an important goal of a "comprehensive" Brexit agreement.

\section{The Brave New World of EU Citizenship}

The UK Government's paper on Northern Ireland maintains that:

The UK welcomes the commitment in the European Commission's directives that these EU rights should continue to be respected following the UK's departure from the EU: "Full account should be taken of the fact that Irish citizens residing in Northern Ireland will continue to enjoy rights as EU citizens".

The problem with this as a legal starting point is that it is a fudge. Irish citizens residing in Northern Ireland will have EU citizen rights - but they will be resident outside of the EU. An analogous example could be a UK national currently living in the United States (or any nonmember state), in which case they have no ability to exercise their EU citizenship rights for as long as their residency of a non-member state continues.

In terms of the four freedoms, the United States example indicates passive enjoyment at best. Post Brexit, an Irish citizen living in Northern Ireland retains the right to live elsewhere in the $\mathrm{EU}$ - and once they exercise that right to move, the full ambit of the four freedoms and EU citizenship rights will apply to them again. However, while they remain resident in Northern Ireland, there is very little in EU citizenship rights that they can concretely benefit from. ${ }^{32}$ In fact, nearly all rights stemming from the EU's 'four freedoms' are conditional on moving to another Member State: see, for instance, the freedom to establish a business in another Member State. ${ }^{33}$ However, those few rights that do not require movement to another Member State will no longer apply to EU nationals resident in Northern Ireland once it is no longer part of a Member State. Key here is the freedom to provide services, which is contingent on living in a Member State and providing a service to another Member State. ${ }^{34}$ While service provision will presumably be covered under the CTA and bilateral agreements vis-à-vis Ireland,

\footnotetext{
${ }^{31}$ Article 21(1) TEU.

${ }^{32}$ See Article 20(2) TFEU, which sets out the primary EU citizenship rights: to 'move to and reside in' any other EU Member State, and to 'vote in and stand for' European Parliament elections and local elections in their Member State of residence.

${ }^{33}$ See Article 49 TFEU, on freedom of establishment.

${ }^{34}$ Article 56 TFEU.
} 
individuals from Northern Ireland will not be able to provide services to the rest of the EU unless they are resident in an EU state with Irish nationality - as opposed to resident in the UK with Irish nationality, or resident in Ireland with UK nationality.

While not exactly analogous, Faroe Island residents demonstrate the consequences of Brexit for Irish passport holders in the UK. While they possess Danish passports, they cannot exercise EU citizenship rights unless resident in Denmark (or elsewhere in the EU). Having an EU passport while residing outside the EU, such as on the Faroe Islands, does not enable you to exercise your EU rights fully.

All of this means that while Irish citizens living in Northern Ireland would have 'dormant' free movement rights that a UK citizen would not have, these rights have very limited impact within Northern Ireland. The one possible exception here is European Parliament voting rights where Ireland could make this right available to Irish nationals living outside of Ireland, but currently does not. This means that even this EU citizenship right, which does not have to be limited by residency in a Member State, would not continue to be enjoyed by Irish nationals living in Northern Ireland.

A possible alternative to this 'loss' of EU rights for those resident in Northern Ireland is a bespoke arrangement with the EU in which Northern Ireland will be treated as if a territory of a Member State. This would be unprecedented, but if successfully negotiated, it results in further, rather than fewer, problems for UK-Irish relations. For one, the principle of consent under the Good Friday Agreement precludes changes to the territorial status of Northern Ireland without agreement from both Irish and Northern Irish voters, so pushing through such a 'status' change via a treaty may be ill-advised. ${ }^{35}$ Secondly, the equivalence of rights mandated by the Good Friday Agreement would run into significant problems if those born in Northern Ireland choosing to hold an Irish passport had the full extent of EU citizenship rights, but those born in Northern Ireland choosing to hold a UK passport did not. Finally, it is also highly doubtful that the EU would agree to extend such treatment to Irish passport holders in Northern Ireland without demanding it be replicated for all other EU nationals resident in Northern Ireland. The loss of 'active' EU citizenship rights for Irish nationals in Northern Ireland, consequently, seems to be the simpler solution - but must be adequately prepared for and communicated to those Irish nationals sooner rather than later.

Clarity on what the EU and the UK understand to be the consequence of Irish nationals in Northern Ireland retaining their EU citizenship is urgently needed. If these Irish nationals will, like all EU nationals residing outside of the EU, have primarily 'dormant' rights that they could choose to exercise by moving to the EU, this must be specified by both parties as soon as possible so those dependent on EU rights like the free movement of services for business purposes can prepare. If, on the other hand, the EU and the UK wish to negotiate a special status for Northern Ireland whereby its territory will be treated as if it were a Member State, the consequences of this for both the Good Friday Agreement and all other EU nationals resident in Northern Ireland must be anticipated by those negotiations.

\footnotetext{
${ }^{35}$ Northern Ireland Act 1998, s1.
} 


\section{The Brave New World of Devolution}

The EU Withdrawal Bill, as introduced, purports to effect little change to the devolution settlement. Clause 11 asserts that retained EU law remains as binding on the competences of the devolved institutions as EU law was before it. The Bill purports to make no direct transfers of power to any of the devolved institutions. The brave new world of devolution is deliberately intended to differ as little as possible from the pre-Brexit arrangements:

To provide the greatest level of legal and administrative certainty upon leaving the EU, and consistent with the approach adopted more generally in legislating for the point of departure, the Government intends to replicate the current frameworks provided by EU rules through UK legislation. ${ }^{36}$

As the Shadow Secretary of State for Exiting the EU recognised on the Bill's introduction, the Bill 'fails to include a presumption of devolution which would allow effective transfer of devolved competencies coming back from the EU to the devolved administrations and makes unnecessary and unjustified alterations to the devolution settlements' ${ }^{37}$ This insistence that (almost) nothing is changing amidst profound change is far from accidental, it is a marker of how toxic relations between the UK Government and the devolved institutions have become, particularly over the issue of Brexit.

The UK Supreme Court's Miller decision affirms that the Westminster Parliament remains able to make laws for the devolved parts of the UK, even if they change the nature of devolved institutional competences, and that this legal power is unaffected by devolution. ${ }^{38}$ The Court nonetheless recognised that a constitutional convention exists whereby the devolved legislatures will normally assent to changes in their competence by means of a Legislative Consent Motion (LCM). ${ }^{39}$ Parliament is therefore under a constitutional duty to gain legislative consent motions from the devolved legislatures on changes to their competence (under the Sewel Convention, as transposed into statute section 2 of the Scotland Act 2016 and section 2 of the Wales Act 2017). The drafting of the Wihdrawal Bill indicates that it was conceived with the intention of denying that a LCM would be necessary, to head off the possibility of a constitutional crisis resulting from Westminster overriding the rejection of a LCM. ${ }^{40}$

The Scottish Executive and Welsh Government are eager to see a range of what are currently EU competences and related funding, particularly with regard to agriculture, fisheries and regional policy, transferred to their remit on the occasion of Brexit. ${ }^{41}$ The UK Government, however, might feel considerable pressure to allocate funding in a radically different way from the EU in response to expectations generated by the Vote Leave campaign. Its White Paper has certainly indicated an intention to 'to ensure that more decisions are devolved', but this leaves

\footnotetext{
${ }^{36} \mathrm{HM}$ Government, Legislating for the United Kingdom's withdrawal from the European Union (2017) Cm 9446, para. 4.4.

${ }^{37}$ HC Debs, vol. 628, col.455 (11 September 2017).

${ }^{38}$ Northern Ireland Act 1998, section 5(6).

${ }^{39} R$ (on the application of Miller) $v$ Secretary of State for Exiting the European Union [2017] UKSC 5, [140].

${ }^{40}$ See European Union Committee, Brexit: Devolution (2017) HL 9, para. 256.

${ }^{41}$ See Scottish Government, Scotland's Place in Europe (Edinburgh, 2016) para. 176 and Welsh Government, Securing Wales' Future (Cardiff, 2017) 28.
} 
open scope for many repatriated competences to be managed by Westminster. ${ }^{42}$ Northern Ireland's Executive, even before the collapse precipitated by the Renewable Heating Incentive scandal, had not clarified its desired outcomes in this regard, likely as a result of the inability of the Executive partners to establish an agreed position.

Relegating devolution issues to the margins of the Withdrawal Bill therefore constitutes an effort to avoid triggering the need for LCMs. This effort was doomed to fail; the Bill as it stands gives new competences to devolved executive members to address reforms consequent upon devolution. ${ }^{43}$ The UK Government has therefore recognised the need to seek LCMs. But to avert a potential constitutional crisis the UK Government needs to recognise the changed nature of the UK constitution since devolution and reach agreements with the devolved administrations on competence transfers and how to manage areas of shared competence which are due to be repatriated. ${ }^{44}$

Brexit has considerable implications for the UK's devolution settlements. Arrangements need to be made not only for repatriating powers but for working out how to legislate for new shared areas of competence, previously managed at EU level by framework Directives. Effective planning for this element of the UK's post-Brexit Constitution will not happen without a constructive partnership between the UK Government and the devolved administrations. This necessarily involves restarting devolution in Northern Ireland.

\section{Conclusions}

Brexit necessarily will bring about change for Northern Ireland and the UK; whatever the disparate motivations of the majority in June 2016 Brexit was a vote against the status quo. The unique impact of that vote upon Northern Ireland has been acknowledged by all relevant parties, London, Belfast, Dublin and Brussels. Nonetheless the consequences for Northern Ireland of a Brexit which draws the UK away from the Customs Union and Single Market have yet to be fully appreciated. Regarding Human Rights protection, if the EU Withdrawal Bill is an indication of the Government's position it does suggest that we will be looking at a changed human rights context. This may not necessarily lead to a violation of the GFA, but steps can be taken now to protect against this risk.

Northern Ireland will need to make itself heard - this is particularly important as Stormont remains dormant. Contingencies will need to be put in place. Trading in the global WTO structure will produce many losers. Significant adjustments will be needed for both small businesses like farms but also Northern Ireland's global manufacturing industries and agri-food businesses.

\footnotetext{
${ }^{42} \mathrm{HM}$ Government, The United Kingdom's exit from and new partnership with the European Union (2017) $\mathrm{Cm}$ 9417, para. 3.5 .

${ }^{43}$ See European Union (Withdrawal) Bill, clause 10.

${ }^{44}$ See European Union Committee, Brexit: Devolution (2017) HL 9, para. 213.
} 